[Regular Paper]

\title{
Oxidative Regeneration of Resid Hydrodesulfurization Catalyst -Effect of Vanadium Accumulation on Properties and Activities of Regenerated Catalyst -
}

\author{
Ryuichiro Iwamoto* and Narinobu KagAmi \\ Petroleum Refining Technology Center, Idemitsu Kosan Co., Ltd., 26 Anegasaki-kaigan, Ichihara, Chiba 299-0107, JAPAN
}

(Received October 2, 2006)

\begin{abstract}
Resid hydrodesulfurization catalyst was regenerated after commercial operation and the effect of vanadium accumulation during resid hydrotreating reaction on the following catalyst regeneration was investigated. Vanadium accumulation accelerated the aggregation of active metals such as $\mathrm{NiMoO}_{4}$. Moreover, vanadium accumulation lead to the formation of $\mathrm{Al}_{2}\left(\mathrm{SO}_{4}\right)_{3}$ on the catalyst during regeneration. Although sulfur-containing species such as $\mathrm{MoS}_{2}$ and vanadium sulfide were present all over the catalyst particle before regeneration, $\mathrm{Al}_{2}\left(\mathrm{SO}_{4}\right)_{3}$ only formed around the exterior of the catalyst particle after regeneration. Since the distribution of $\mathrm{Al}_{2}\left(\mathrm{SO}_{4}\right)_{3}$ corresponded well to the vanadium distribution, vanadium species probably catalytically oxidized $\mathrm{SO}_{2}$ into $\mathrm{H}_{2} \mathrm{SO}_{4}$, and then transformed the alumina carrier around the vanadium to sulfate. The effect of vanadium accumulation on the resid hydrotreatment activities of the resulting regenerated catalyst was also investigated. The hydrodesulfurization, hydrodenitrogenation and hydrodemicrocarbon residue activities over the regenerated catalyst decreased with increasing amount of vanadium accumulation. Since the XRD results indicated that the formation of $\mathrm{NiMoO}_{4}$ increased with vanadium accumulation, the deactivation of HDS activity probably resulted from the decrease in the number of active sites due to aggregation of nickel and molybdenum. On the other hand, hydrodemetallization and hydrodeasphaltene activities increased with increasing amount of vanadium accumulation. Vanadium sulfide accumulated on the catalyst may have formed new hydrodemetallation and hydrodeasphaltenization active sites.
\end{abstract}

\section{Keywords}

Oxidative regeneration, Resid hydrodesulfurization, Hydrodemetallation, Hydrodenitrogenation,

Vanadium accumulation

\section{Introduction}

Human activity generates large amounts of various types of waste which are having an increasing and cumulative effect on the world environment. Therefore, many enterprises are trying to achieve zero emissions of waste through modification of manufacturing processes. The petroleum industries are also making great efforts to reduce emissions of wastes and to build environmentally friendly refineries. One of the most important types of waste from refineries is the hydrodesulfurization (HDS) catalyst used for the resid fraction, as large volumes of this catalyst are exchanged every year due to the high deactivation rate. Therefore, regeneration and reuse of resid HDS catalyst would greatly reduce the waste from refineries. However, the resid HDS catalyst is not generally regenerated but is sent for metal recovery, whereas the HDS catalysts

\footnotetext{
* To whom correspondence should be addressed.

* E-mail: ryuichiro.iwamoto@si.idemitsu.co.jp
}

for lighter fractions such as gas oil and kerosene are commonly regenerated.

Deactivation mechanisms occurring during hydrotreatment have been extensively studied, but the regeneration mechanism and deactivation mechanism during regeneration are less well known, especially for resid HDS catalyst. Reuse of resid HDS catalyst requires understanding of the regeneration behavior. In general, regeneration of resid HDS catalyst can be classified into oxidative regeneration and rejuvenation. Oxidative regeneration is based on burning of accumulated coke, and rejuvenation is intended to reduce contamination by accumulated metals such as vanadium. Here, we will discuss the oxidative regeneration of resid HDS catalyst.

The oxidative regeneration mechanism of hydrotreatment catalyst has been studied and reviewed in detail $^{1)}$. Coke and contaminant metals ( $\mathrm{Ni}, \mathrm{V}$ and $\mathrm{Fe}$ ) are accumulated on resid catalyst during operation. Normally, such metals are present as sulfides, as are the active metals such as $\mathrm{MoS}_{2}$ and $\mathrm{Co}_{9} \mathrm{~S}_{8}$. For example, 
vanadium is considered to be accumulated as $\mathrm{V}_{3} \mathrm{~S}_{4}{ }^{2}$. These metals and coke are oxidized by the regeneration process.

The oxidative regeneration reaction consists of the following reactions ${ }^{3), 4)}$.

$$
\begin{aligned}
& \mathrm{C}+\mathrm{O}_{2}=\mathrm{CO}_{2} \\
& 2 \mathrm{C}+\mathrm{O}_{2}=2 \mathrm{CO} \\
& 4 \mathrm{H}_{\mathrm{org}}+\mathrm{O}_{2}=2 \mathrm{H}_{2} \mathrm{O} \\
& \mathrm{MS}_{x}+y \mathrm{O}_{2}=\mathrm{MO}_{z}+x \mathrm{SO}_{2}
\end{aligned}
$$

where $\mathrm{H}_{\text {org }}$ refers to the hydrogen content of the coke, and $\mathrm{M}$ refers to metals on the catalyst such as $\mathrm{Co}, \mathrm{Ni}$, Mo, W, V and Fe. During oxidative regeneration, the states of coke, active metals, accumulated metals, and support change significantly ${ }^{4) \sim 8)}$. For the active metal species, the formation of $\beta-\mathrm{NiMoO}_{4}, \mathrm{MoO}_{3}, \mathrm{Al}_{2}\left(\mathrm{MoO}_{4}\right)_{3}$, $\mathrm{FeMoO}_{4}$ and $\mathrm{NiAl}_{2} \mathrm{O}_{4}$ occur depending on the regeneration condition and nature of catalyst. Alumina support could also transform $\gamma-\mathrm{Al}_{2} \mathrm{O}_{3}$ to $\delta-\mathrm{Al}_{2} \mathrm{O}_{3}$ or $\alpha-\mathrm{Al}_{2} \mathrm{O}_{3}$ caused by the exothermal reaction due to coke combustion $^{5)}$. Vanadium sulfide on catalyst transforms to $\mathrm{V}_{2} \mathrm{O}_{5}$ by oxidation ${ }^{5}$.

Regeneration temperatures which are too high will not completely restore the activity due to sintering of active metals, even if the specific surface area recovers to the level of fresh catalyst ${ }^{3)}$. Vanadium accumulation may prevent restoration of activity due to blocking of the pore structure and active sites ${ }^{9)}$. Vanadium may also prevent redispersion of the active metals ${ }^{7)}$. However, regeneration under certain conditions leads to higher HDS activity compared to fresh catalyst because of greater active metal dispersion ${ }^{10), 11)}$. Therefore, the chemistry of HDS catalyst regeneration is not yet well understood. In particular, the effect of vanadium accumulation on the regeneration of resid HDS catalyst has been not clarified.

The present study investigated the effect of vanadium accumulation by characterization and activity tests of regenerated resid HDS catalysts with different amounts of vanadium accumulation.

\section{Experimental}

\section{1. Catalyst Preparation}

The catalyst was conventional $\mathrm{NiO}-\mathrm{MoO}_{3}-\mathrm{P}_{2} \mathrm{O}_{5} /$ $\mathrm{Al}_{2} \mathrm{O}_{3}$ prepared by impregnating $\gamma$-alumina with $\mathrm{Ni}-\mathrm{Mo}^{-} \mathrm{P}$ solution. The preparation method was already described elsewhere ${ }^{12)}$. The catalyst was loaded into a commercial atmospheric residue hydrodesulfurization unit (ARDS) and then operated to produce fuel oil with sulfur content of $c a$. $0.3 \mathrm{wt} \%$. After commercial operation for 1 year, catalyst samples with different amounts of contaminant metal accumulation (vanadium and nickel) were obtained from different parts of the reactor, as the metal content depends on the loading position and operating conditions. The used catalysts obtained were dried in an oven under nitrogen at $573 \mathrm{~K}$ for $3 \mathrm{~h}$ and then calcined in air at $723 \mathrm{~K}$ for $3 \mathrm{~h}$ for regeneration.

\section{2. Catalyst Characterization}

The concentrations of various metals $(\mathrm{V}, \mathrm{Ni}, \mathrm{Mo})$ on the catalyst were determined by inductively coupled plasma analysis (ICP) using a SPS5100 (SII Nanotechnology Inc.) Coke and sulfur on the catalyst were analyzed by LECO meter using a CS-444LS (LECO Corp.). The surface area was measured by nitrogen adsorption using an Autosorb-6 (Quantachrome Instruments). The structural change of the catalyst and the dispersion of $\mathrm{Ni}-\mathrm{Mo}$ precursors were investigated by X-ray diffractometer equipped with a goniometer, a monochromator, and a $\mathrm{Cu} \mathrm{X}$-ray tube using a RINT Ultima III (RIGAKU). Distributions of the catalyst components through the catalyst particles were measured by electron probe micro analysis (EPMA) using a JXA-8200 (JEOL).

\section{3. Catalytic Activity Measurement}

Resid hydrotreatment was carried out with a fixed bed high pressure flow micro reactor to measure the activity of regenerated catalyst. The feedstock was Middle East atmospheric residue containing $3.73 \mathrm{wt} \%$ sulfur, $2240 \mathrm{ppm}$ nitrogen, $11.5 \mathrm{wt} \%$ micro carbon resid, $4.8 \mathrm{wt} \% n-\mathrm{C}_{7}$ insoluble (asphaltene), $74 \mathrm{ppm}$ vanadium and $26 \mathrm{ppm}$ nickel with density $0.9745 \mathrm{~g} / \mathrm{m} l$. Catalyst $(50 \mathrm{ml})$ with the original shape was loaded into the reactor without dilution. The catalyst was presulfided with $2.0 \mathrm{wt} \%$ dimethyl disulfide (DMDS) dissolved in light gas oil for $24 \mathrm{~h}$. The HDS, hydrodenitrogenation (HDN), hydrodemetallization (HDM), hydrodemicrocarbon residue (HDMCR) and hydrodeasphaltenization (HDAs) activities were measured at 633 to $653 \mathrm{~K}$, LHSV $0.28 \mathrm{~h}^{-1}, 13 \mathrm{MPa}$ and $\mathrm{H}_{2} /$ oil $=$ $700 \mathrm{~N} l / l$ at time on stream of 100 to $300 \mathrm{~h}$. The sulfur content of the product oil was analyzed with a sulfur meter RX-610SA (TANAKA SCIENCE). The part of the $\mathrm{H}_{2} \mathrm{~S}$ formed during the HDS reaction dissolved in the product oil was removed by stripping with nitrogen gas before the sulfur analysis. Product nitrogen, vanadium and nickel on catalyst were analyzed by ICP.

The activities were evaluated on the basis of the reaction rate as follows.

$k=\mathrm{LHSV} /(n-1) \times\left(\left(1 / P_{1}\right)^{n-1}-\left(1 / P_{0}\right)^{n-1}\right)($ in case of $n>1)$ or $k=\mathrm{LHSV} \times \ln \left(P_{0} / P_{1}\right) \quad$ (in case of $n=1$ ) $n$ : reaction order (HDS: $n=1.6, \mathrm{HDN}, \mathrm{HDM}, \mathrm{HDMCR}$ and HDAs: $n=1$ )

$P_{0}$ : feed concentration (wt $\%$ or $\left.\mathrm{ppm}\right)$

$P_{1}$ : product concentration (wt $\%$ or $\mathrm{ppm}$ )

\section{Results}

\section{1. Properties of Regenerated Catalyst}

Properties of the regenerated catalysts are shown in Table 1. The sulfur on the regenerated catalyst increased with greater vanadium accumulation, which 
Table 1 The Properties of Regenerated Catalyst

\begin{tabular}{|c|c|c|c|c|c|c|c|}
\hline \multirow[b]{2}{*}{ Catalyst } & \multicolumn{4}{|c|}{ Before regeneration } & \multicolumn{3}{|c|}{ After regeneration } \\
\hline & $\begin{array}{c}\text { Vanadium }^{\mathrm{a})} \\
{[\mathrm{wt} \%]}\end{array}$ & $\begin{array}{l}\text { Nickel }^{\mathrm{a})} \\
{[\mathrm{wt} \%]}\end{array}$ & $\begin{array}{l}\text { Coke } \\
{[\mathrm{wt} \%]}\end{array}$ & $\begin{array}{l}\text { Sulfur } \\
{[\mathrm{wt} \%]}\end{array}$ & $\begin{array}{l}\text { Coke } \\
{[\mathrm{wt} \%]}\end{array}$ & $\begin{array}{l}\text { Sulfur } \\
{[\mathrm{wt} \%]}\end{array}$ & $\begin{array}{l}\text { S.A. } \\
{\left[\mathrm{m}^{2} / \mathrm{g}\right]}\end{array}$ \\
\hline Fresh catalyst & - & - & - & - & - & - & 172 \\
\hline Regenerated catalyst- 1 & $0.7^{\text {b) }}$ & 1.1 & 26.6 & 4.3 & 0.67 & 0.20 & 166 \\
\hline Regenerated catalyst- 2 & 1.4 & 1.1 & 18.4 & 6.3 & 0.90 & 0.82 & 164 \\
\hline Regenerated catalyst-3 & 2.0 & 1.5 & 19.9 & 6.5 & 0.57 & 1.25 & 147 \\
\hline
\end{tabular}

a) Vanadium and nickel accumulation calculated based on the fresh catalyst.

b) Precise quantitative analysis is $>1.0 \mathrm{wt} \%$.

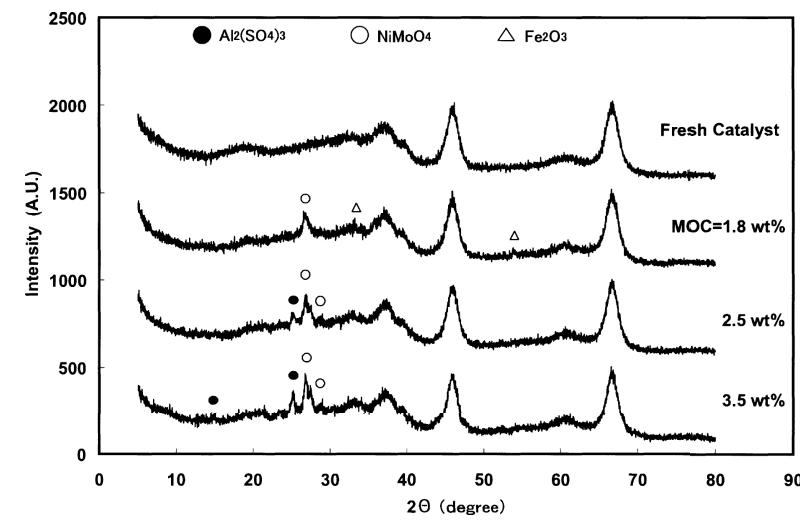

$\mathrm{MOC}=1.8 \mathrm{wt} \%:$ regenerated catalyst $-1, \mathrm{MOC}=2.5 \mathrm{wt} \%:$ regenerated catalyst -2 , and $\mathrm{MOC}=3.5 \mathrm{wt} \%$ : regenerated catalyst -3 .

Fig. 1 X-Ray Diffraction Patterns of the Fresh and Regenerated Catalysts

was not due to incomplete regeneration, because the coke on the catalyst was reduced to an adequately low level. Specific surface area also decreased with greater vanadium accumulation, especially above $2 \mathrm{wt} \%$.

\section{2. Structural Change of Regenerated Catalyst}

The total amount of vanadium and nickel accumulation as metal during the HDM reaction based on fresh catalyst was defined as Metal on Catalyst (MOC). Figure 1 shows the effect of MOC on the structure of the regenerated catalyst measured by X-ray diffraction (XRD). The fresh catalyst showed only broad peaks belonging to the $\gamma$-alumina support, and no peaks for nickel or molybdenum compounds. However, the regenerated catalysts-1, 2 and 3 showed peaks assigned to $\mathrm{NiMoO}_{4}$, which indicates the presence of aggregated nickel and molybdenum components. Furthermore, other peaks for $\mathrm{Al}_{2}\left(\mathrm{SO}_{4}\right)_{3}$ were observed above $2.5 \mathrm{wt} \%$ of MOC (regenerated catalysts-2 and 3). The peak intensities of $\mathrm{NiMoO}_{4}$ and $\mathrm{Al}_{2}\left(\mathrm{SO}_{4}\right)_{3}$ increased with increasing amount of MOC. Regenerated catalyst-1 showed two peaks assigned to $\mathrm{Fe}_{2} \mathrm{O}_{3}$. This iron species is attributed to contamination by scale due to process corrosion. Therefore, this finding was excluded from this discussion.

Observation of the cross section of the regenerated

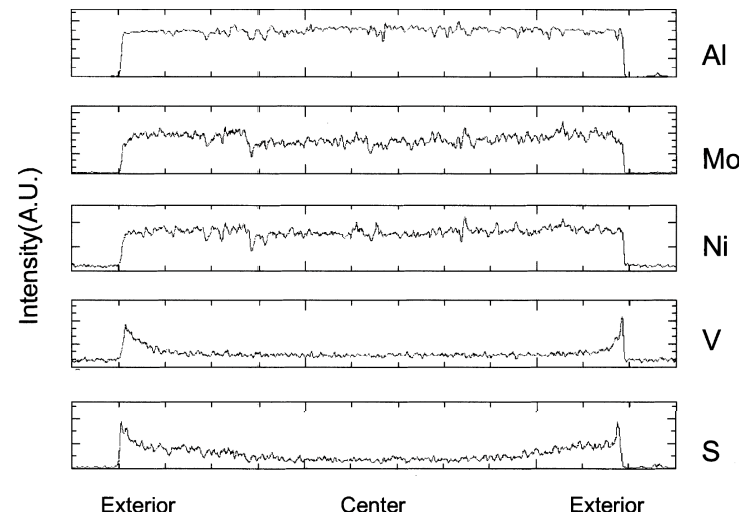

Fig. 2 EPMA Line Analysis of the Regenerated Catalyst (MOC= $8 \mathrm{wt} \%)$

catalyst showed that the exterior of catalyst particle was yellow whereas the interior was the original light green. Figure 2 shows the EPMA line analysis of aluminum, molybdenum, nickel, vanadium and sulfur for the regenerated catalyst (to emphasize the effect of vanadium on the distribution of the catalyst component, the sample with $\mathrm{MOC}=8.1 \mathrm{wt} \%$ was used). The EPMA measurement indicated that vanadium and sulfur tended to accumulate around the exterior of the catalyst particle. The yellow exterior of catalyst particle might be due to the vanadium accumulation. Figure 2 shows that the distribution of sulfur and vanadium was quite similar. In contrast, nickel, molybdenum and aluminum had almost uniform distributions over the catalyst particle as well as the original fresh catalyst.

\section{3. Activity of Regenerated ARDS Catalyst}

Figure 3 shows the relationship between MOC and HDS activity over the fresh catalyst, regenerated catalyst- 1 and regenerated catalyst-3. The HDS activity decreased gradually with increasing amount of metal accumulation. The regenerated catalysts showed the same activation energy as the fresh catalyst ( $c a$. $25,000 \mathrm{cal} / \mathrm{mol}$ ) which did not change significantly with MOC.

Figure 4 shows the relationship between MOC and HDN activity over the fresh catalyst, regenerated catalyst- 1 and regenerated catalyst-3. The HDN activity also decreased with increasing amount of MOC. The 


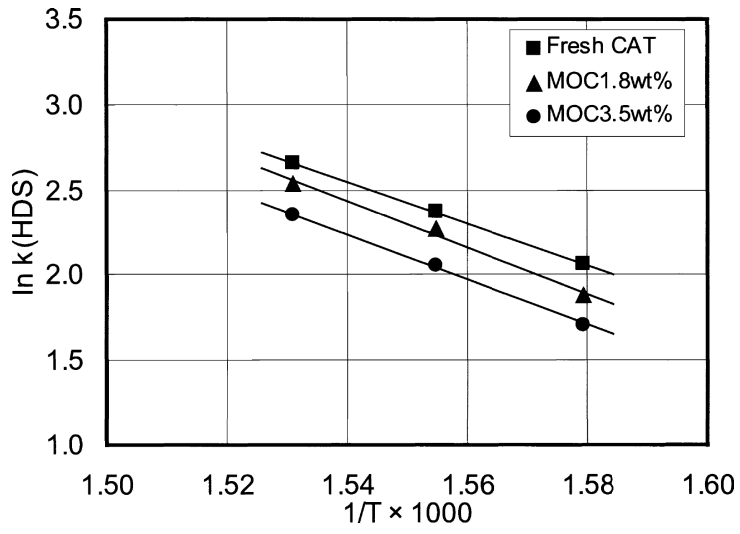

$\mathrm{MOC}=1.8 \mathrm{wt} \%:$ regenerated catalyst -1 and $\mathrm{MOC}=3.5 \mathrm{wt} \%:$ regenerated catalyst- 3 .

Fig. 3 HDS Activity of the Fresh and Regenerated Catalysts

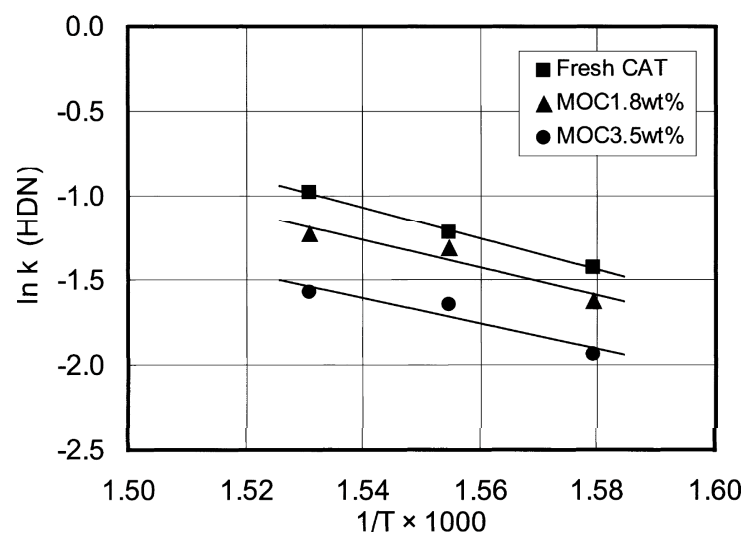

$\mathrm{MOC}=1.8 \mathrm{wt} \%:$ regenerated catalyst -1 and $\mathrm{MOC}=3.5 \mathrm{wt} \%:$ regenerated catalyst 3 .

Fig. 4 HDN Activity of the Fresh and Regenerated Catalysts

activation energy of HDN was almost the same as the fresh catalyst ( $c a .18,000 \mathrm{cal} / \mathrm{mol}$ ) but the deviation was rather larger.

Figures 5 and $\mathbf{6}$ show the relationships between MOC and hydrodevanadiumation (HDV), and hydrodenickelation (HDNi) activities over the fresh catalyst, regenerated catalyst- 1 and regenerated catalyst-3, respectively. In contrast to the HDS and HDN results, the HDV and HDNi activities increased with increasing amount of MOC. The activation energy of HDV may also increase with MOC from $c a$. 11,000 to 15,000 cal/ mol. The activation energy of HDNi was $c a$. $12,000 \mathrm{cal} / \mathrm{mol}$ and the deviation was relatively larger.

Figure 7 shows the relationship between MOC and hydrodemicrocarbon residue activity (HDMCR) over the fresh catalyst, regenerated catalyst- 1 and regenerated catalyst -3 . The HDMCR activity decreased with increasing amount of MOC, like the HDS activity. The activation energy of HDMCR also decreased with

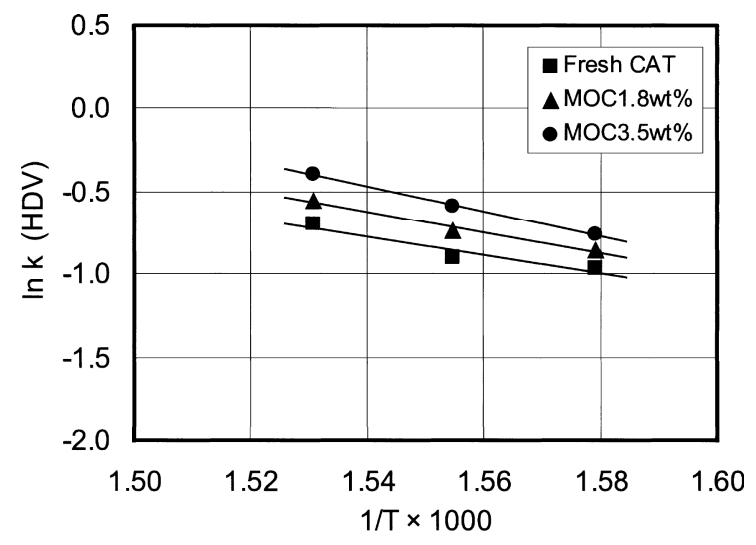

$\mathrm{MOC}=1.8 \mathrm{wt} \%:$ regenerated catalyst -1 and $\mathrm{MOC}=3.5 \mathrm{wt} \%:$ regenerated catalyst-3.

Fig. 5 HDV Activity of the Fresh and Regenerated Catalysts

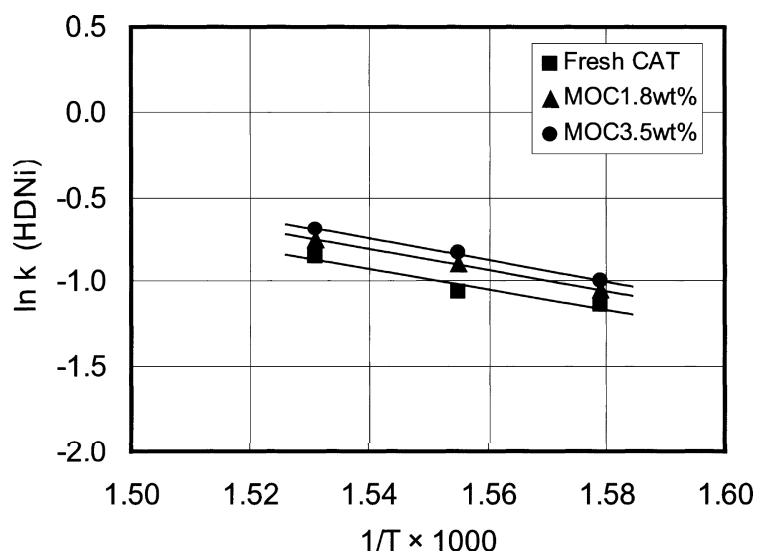

$\mathrm{MOC}=1.8 \mathrm{wt} \%:$ regenerated catalyst -1 and $\mathrm{MOC}=3.5 \mathrm{wt} \%:$ regenerated catalyst -3 .

Fig. 6 HDNi Activity of the Fresh and Regenerated Catalysts

MOC from $\mathrm{ca}$. 12,000 to $9000 \mathrm{cal} / \mathrm{mol}$ and the deviation was rather larger. Figure 8 similarly shows that the hydrodeasphaltene activity (HDAs) increased with increasing amount of MOC, like the HDM activity. The activation energy of HDAs seemed to decrease with MOC from $c a$. 19,000 to $15,000 \mathrm{cal} / \mathrm{mol}$.

\section{Discussion}

The present study found that vanadium accumulation enhanced the aggregation of $\mathrm{NiMoO}_{4}$ (Fig. 1). It is not clear whether the aggregation of active metal species occurred during the hydrotreatment reaction and/or during the regeneration procedure. However, the regeneration procedure is likely to be the main contributor to the aggregation of active metals, since the aggregation of $\mathrm{Ni}$ and Mo sulfide is not obvious in the used catalyst and the regeneration procedure significantly changes the support properties such as the formation of 


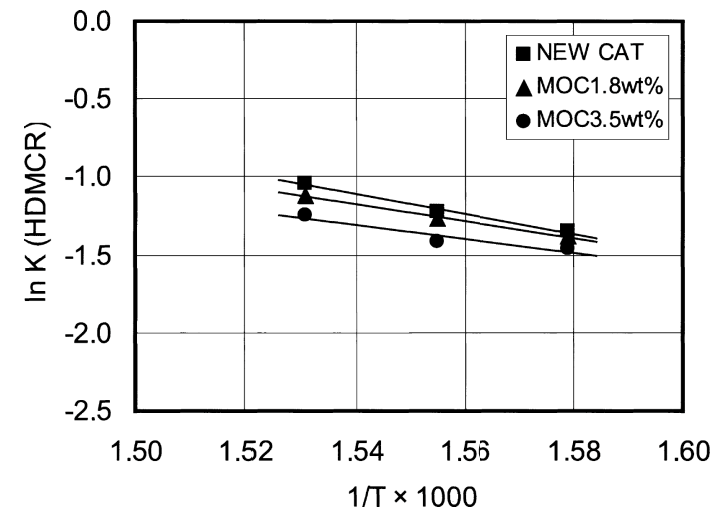

$\mathrm{MOC}=1.8 \mathrm{wt} \%:$ regenerated catalyst -1 and $\mathrm{MOC}=3.5 \mathrm{wt} \%:$ regenerated catalyst-3.

Fig. 7 HDMCR Activity of the Fresh and Regenerated Catalysts

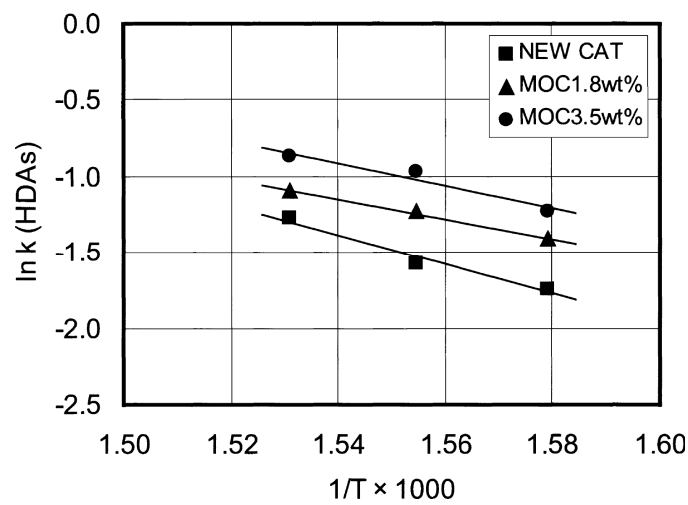

$\mathrm{MOC}=1.8 \mathrm{wt} \%:$ regenerated catalyst -1 and $\mathrm{MOC}=3.5 \mathrm{wt} \%:$ re generated catalyst-3.

Fig. 8 HDAs Activity of the Fresh and Regenerated Catalysts

\section{$\mathrm{Al}_{2}\left(\mathrm{SO}_{4}\right)_{3}$.}

The amount of sulfur on the regenerated catalyst increased with increasing amount of vanadium as shown in Table 1. The accumulation of sulfur can be attributed to the formation of $\mathrm{Al}_{2}\left(\mathrm{SO}_{4}\right)_{3}$, based on the results of XRD and EPMA measurements in Figs. 1 and 2. The distributions of sulfur and vanadium were quite similar. Vanadium species are well known to accumulate around the exterior of the catalyst particle due to the relatively higher HDV reaction rate ${ }^{13), 14)}$. One possibility is that the sulfur component of vanadium sulfide reacts with the alumina support. However, the amount of sulfur combined in molybdenum sulfide is similar all over the catalyst particle. Therefore, $\mathrm{Al}_{2}\left(\mathrm{SO}_{4}\right)_{3}$ should form anywhere over the catalyst, although the sulfur is present only on the exterior of the catalyst particle as shown by EPMA (Fig. 2). Another possibility is that the vanadium on the exterior of the catalyst may catalytically oxidize $\mathrm{SO}_{2}$ to $\mathrm{H}_{2} \mathrm{SO}_{4}$ during the regeneration, and then the surrounding alumina sup- port is transformed to sulfate, since vanadium oxide is an excellent oxidation catalyst. The reaction can be described as the following equations.

$$
\begin{aligned}
& 4 \mathrm{H}_{\mathrm{org}}+\mathrm{O}_{2}=2 \mathrm{H}_{2} \mathrm{O} \\
& \mathrm{MS}_{x}+y \mathrm{O}_{2}=\mathrm{MO}_{z}+x \mathrm{SO}_{2} \\
& \mathrm{SO}_{2}+1 / 2 \mathrm{O}_{2}=\mathrm{SO}_{3} \\
& \mathrm{SO}_{3}+\mathrm{H}_{2} \mathrm{O}=\mathrm{H}_{2} \mathrm{SO}_{4} \\
& 3 \mathrm{H}_{2} \mathrm{SO}_{4}+\mathrm{Al}_{2} \mathrm{O}_{3}=\mathrm{Al}_{2}\left(\mathrm{SO}_{4}\right)_{3}+3 \mathrm{H}_{2} \mathrm{O}
\end{aligned}
$$

This type of $\mathrm{Al}_{2}\left(\mathrm{SO}_{4}\right)_{3}$ formation might be a unique phenomenon during the regeneration of resid HDS catalyst.

The HDS, HDN and HDMCR activities decreased with increasing amount of MOC (Figs. 3 and 4). Since the XRD results indicated that the formation of $\mathrm{NiMoO}_{4}$ increases with MOC, the deactivation of HDS mainly results from the decrease in the number of active sites due to aggregation of nickel and molybdenum. The HDS mechanism may not change with the accumulation of contaminant metals, as the activation energy does not change obviously. The effect of nickel accumulation is rather difficult to elucidate. However, the nickel accumulation might act as a poison for the HDS reaction, because the nickel content of fresh HDS catalyst is already optimized and excess nickel loading on the catalyst tends to decrease HDS activity ${ }^{15)}$. The decrease in HDN activity might indicate a decrease in hydrogenation activity. The HDMCR and HDS activities normally show a good correlation, as seen in this study.

On the other hand, the HDV activity and the activation energy increased with increasing amount of MOC as shown in Fig. 5. This result suggests that the accumulated vanadium sulfide forms new HDM active sites. The accumulated vanadium sulfide may trap other vanadium in the feed. This result well agrees with the previous result that vanadium accumulation on regenerated catalyst increases the selectivity of HDM ${ }^{16)}$. Furthermore, HDAs and HDM activities showed almost the same trend. Vanadium accumulation might enhance the scission of the $\mathrm{V}-\mathrm{C}$ bond in heavier molecular fractions.

Coke accumulation might also affect the regeneration behavior and resulting catalytic activity. However, the amount of coke was not the main factor in this discussion, because of the lower correlation with the activity as shown in Fig. 9. The effect of pore structure was also excluded, as the pore structure was not obviously changed by the regeneration procedure in this study. Therefore, the MOC may be the most important factor affecting the activity of the regenerated resid HDS catalyst.

\section{Conclusion}

The effect of vanadium accumulation during the resid hydrotreatment reaction on oxidative catalyst re- 

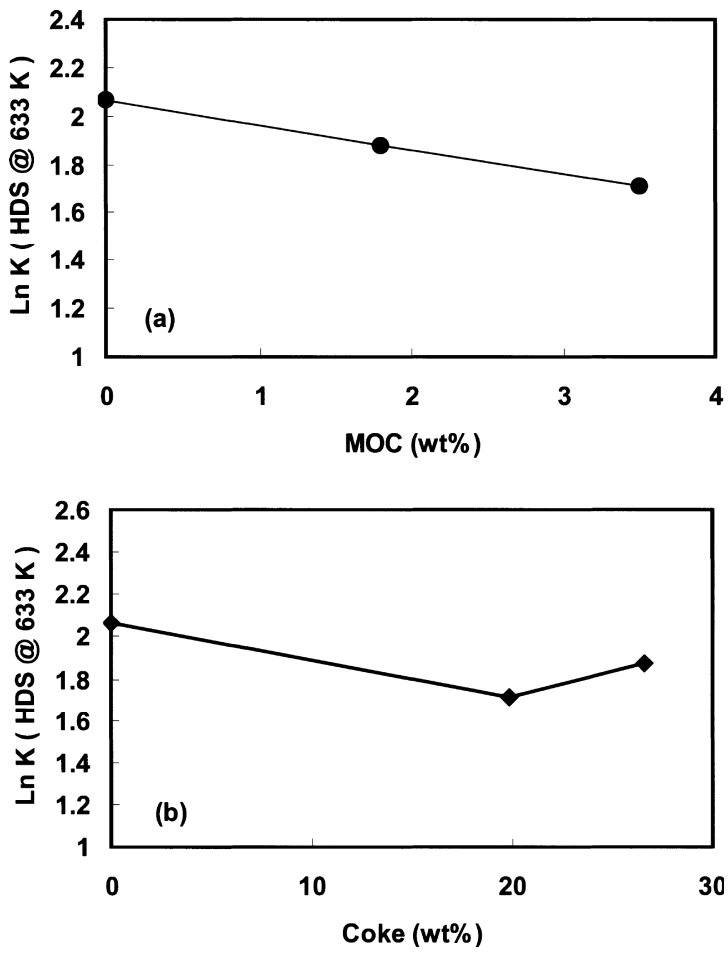

(a) Relationship between MOC and HDS activity, (b) Relationship between coke and HDS activity.

Fig. 9 Relationship between the Catalyst Properties before Regeneration and HDS Activity of the Regenerated Catalysts

generation was investigated. The accumulation of vanadium species on the resid HDS catalyst led to the formation of $\mathrm{NiMoO}_{4}$ and $\mathrm{Al}_{2}\left(\mathrm{SO}_{4}\right)_{3}$. The accumulated vanadium might oxidize $\mathrm{SO}_{2}$ into $\mathrm{H}_{2} \mathrm{SO}_{4}$ and then transform the alumina support into $\mathrm{Al}_{2}\left(\mathrm{SO}_{4}\right)_{3}$. The vanadium accumulation decreased resid HDS, HDN and HDMCR activities due to the formation of $\mathrm{NiMoO}_{4}$. On the other hand, HDM and HDAs activities increased with increasing amount of metal accumulation.
Therefore, vanadium sulfide accumulated on the catalyst may form new HDM active sites.

\section{Acknowledgments}

This study was carried out under the auspices of the Japan Petroleum Energy Center (JPEC).

\section{References}

1) Furimsky, E., Massoth, F. E., Catal. Today, 17, 537 (1993).

2) Callejas, M. A., Martínez, M. T., Fierro, J. L. G., Rial, C., Jimenéz-Mateos, J. M., Gómez-García, F. J., Appl. Catal. A: General, 220, 93 (2001).

3) Trimm, D. L., "Catal. in Prtroleum Refining 1989," Elsevier, Amsterdam, (1990), p. 41.

4) George, Z. M., Mahammed, P., Tower, R., Proc. 9th Int., Congr. Catal., 1988, p. 230.

5) Teixeira da Silva, V. L. S., Grety, R., Schmal, M., Ind. Eng. Chem. Res., 33, 1692 (1994).

6) Madeley, R. A., Wanke, S. E., Appl. Catal., 39, 295 (1988).

7) Kim, C. S., Massoth, F. E., Furimsly, E., Fuel Proccessing Technol., 32, 39 (1992).

8) Marinković-Nedučin, R., Bošković, G., Kiš, E., Lomić, G., Hantsche, H., Mićić, R., Pavlović, P., Appl. Catal. A: Geneal, 107, 133 (1994).

9) Alvarez, D., Galiasso, R., Andréu, P., Sekiyu Gakkaishi (J. Jpn. Petrol. Inst.), 22, (4), 234 (1979).

10) Arteaga, A., Fierro, J. L. G., Grange, P., Demon, B., Proceeding of symposium on advances in hydrotreating, ACS, Denver, 1987, p. 339.

11) Oh, E. S., Yong-Chul Park, Y. C., Lee, I. C., Rhee, H. K., J. Catal., 172, 314 (1997).

12) Iwamoto, R., Kagami, N., Sakoda, Y., Iino, A., J. Jpn. Petrol. Inst., 48, (6), 351 (2005).

13) Beaton, W. I., Bertolacini, R. J., Catal. Rev.-Sci. Eng., 33, (3\&4), 281 (1991).

14) Babcock, K. W., Hiltzik, L., Ernst, W. R., Appl. Catal., 51, 295 (1989).

15) Iwamoto, R., Inamura, K., Nozaki, T., Iino, A., Appl. Catal. A: General, 163, 217 (1997).

16) Guibard, I., Kressmann, S., Morel, F., Harle, V., Dufresne, P., http: //www. eurecat. fr/eurecat/gb/technical_doc/A_fresh_ performance_2. pdf 
要旨

\title{
重油脱硫触媒の再生 \\ 一バナジウム蓄積が再生触媒の物性と活性に与える影響一
}

\author{
岩本 隆一郎, 各務 成存 \\ 出光興産 (株) 石油技術センター, 299-0107 千葉県市原市姉崎海岸26番地
}

商業装置で 1 年間運転された重油脱硫触媒を再生し, バナジ
ウムの蓄積量が再生触媒の物性拉よび活性に与え影響につい
て検討した。XRD測定からバナジウムの蓄積量に比例して再
生時に $\mathrm{NiMoO}_{4}$ のような活性金属の凝集が促進されることが分
かった。また, バナジウムの蓄積量に比例して再生時に硫酸ア
ルミニゥムの生成が促進されることを見出した。硫酸アルミニ
ウムとなる硫黄源は再生前にはモリブデン硫化物やバナジウム
硫化物として触媒上に十分存在しているにもかかわらず, 硫酸
アルミニウムの分布はバナジウムの分布とよく一致して触媒粒
子の外表面近傍にしか存在しなかった。この理由として, バナ
ジウムの酸化活性が再生時に生成する $\mathrm{SO}_{2}$ を酸化して硫酸を生 成し, さらにこの硫酸が担体のアルミナの硫酸化を促進してい ると考えられる。さらに, バナジウムの蓄積が再生触媒の触媒 活性に与える影響について検討した結果, 重油脱硫活性, 脱窒 素活性, 脱残炭活性はバナジウムの蓄積量に比例して低下した。 この活性低下の原因は活性金属の凝集によると考えられる。一 方, 脱バナジウム活性, 脱ニッケル活性, 脱アスファルテン活 性は, バナジウムの蓄積量に比例して向上した。これは蓄積バ ナジウム自身が新たな活性点となり, 重質留分の反応性を促進 していると考えられる。 